\title{
Electrical Wing Prototype Anti Icing pada Pesawat Komersil
}

\author{
Elfitra Desifatma*1, Muhammad Irwan ${ }^{2}$, Iftitah Rahmi Kadir ${ }^{3}$, Prihandhanu Mukti Pratomo ${ }^{4}$ \\ ${ }^{1,2,3}$ Avionika, Fakultas Teknik, Universitas Nurtanio, Bandung, Indonesia \\ ${ }^{4}$ Fisika, Fakultas MIPA, ITB, Bandung, Indonesia

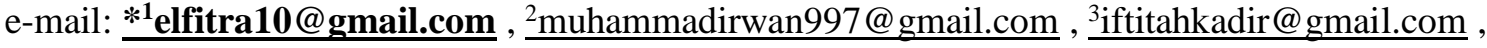 \\ Pmukti.pratomo@gmail.com
}

\begin{abstract}
The accumulation of ice on the aircraft's wings can cause a decrease in the aerodynamic properties of the aircraft, increase in weight, and it is difficult to control the aircraft so that it affects aircraft safety. Icing handling on aircraft is growing. One of the newest systems being developed is electrical anti-icing. Therefore, the researcher designed a prototype of an anti-icing electrical wing on a commercial aircraft with advantages in terms of maintenance and lighter components. The purpose of making this prototype is to design an anti-icing electrical wing in the form of a prototype and can be used as an anti-icing. The prototype consists of three parts, namely input, control unit, and heating element. The heating element working system is by attaching the heating element to the surface of the wing, so when the tool is active through the controls, the heating element will work with an indication of the LED on. After testing the Prototype electrical anti-icing function that has been made, it can be used as a de-icing that removes icing that has already frozen on the leading edge.
\end{abstract}

Keywords : anti icing, Control unit, De-Icing Boot, heating element

\section{PENDAHULUAN}

Icing merupakan pembentukan formasi es selama penerbangan pesawat melewati awan yang berupa tetesan air yang sangat dingin selama ground operation dalam kondisi visibility yang rendah dan suhu udara mendekati titik beku. Bagian pada pesawat yang paling rentan terjadinya icing adalah wing pesawat. Penumpukan es pada sayap pesawat ini dapat menyebabkan penurunan sifat aerodinamis pesawat, pertambahan berat, dan sulit mengendalikan atau memanuver pesawat sehingga berpengaruh pada tingkat keselamatan pesawat. Pembekuan dalam penerbangan untuk pesawat merupakan perhatian besar bagi semua yang terlibat dalam operasi pesawat. Umumnya, pemanas listrik telah digunakan untuk mencegah terjadinya icing dalam penerbangan (Morita et al., 2020) Secara umum, fenomena icing sangat bergantung pada banyak faktor. Diantara ada tiga faktor, yaitu kadar air cair (Liquid Water Content, LWC), suhu lingkungan, dan ukuran tetesan, dianggap penting untuk memprediksi icing. Di sini, LWC mewakili jumlah air yang terkondensasi per unit volume, sedangkan diameter volumetrik sedang (MVD) mewakili ukuran tetesan yang khas. Suhu lingkungan mempengaruhi karakteristik es. Dengan demikian, lapisan es terbentuk di bawah kondisi suhu lingkungan yang relatif tinggi dan rendah (Uranai et al., 2020).

De-icing pesawat selama ground operation sangat penting untuk memaksimalkan keamanan teknis, tetapi juga merupakan tantangan besar bagi orang yang melakukannya (Landau et al., 2017). Selama musim dingin, pesawat di darat terkena kontaminasi akibat cuaca dingin dan keras. Bentuk-bentuk kontaminasi ini, seperti embun beku, salju, hujan beku, dan lain-lain yang mempengaruhi aerodinamis kinerja kendaraan udara dan dapat menyebabkan situasi berbahaya. Untuk mengatasi masalah tersebut, ground de-icing dan cairan anti-icing digunakan untuk membersihkan pesawat dari kontaminasi yang terkumpul dan melindunginya dari pengendapan yang berkelanjutan sebelum dan selama prosedur lepas landas (Villeneuvu et al., 2019). Uji anti- 
icing dilakukan dengan menggunakan terowongan angin icing untuk melihat berapa banyak es yang terkumpul di permukaan dalam kondisi dinamis (Sarshar et al., 2018). Kemampuan de-icing dari sistem udara hangat diselidiki untuk tipikal bagian ujung bilah rotor. Perbandingan dengan sistem anti-icing kontinyu yang biasanya digunakan menunjukkan sistem de-icing menawarkan pengurangan yang luar biasa dari konsumsi energi yang diperlukan untuk operasi sistem pencegahan es (Battisti et al., 2006)

Kebutuhan yang luas mengenai penelitian dan pengembangan teknik baru mengenai penghilangan es konduktor transmisi diamati dengan metode yang ada saat ini, sangat tidak dapat diandalkan karena berisiko tidak hanya terhadap stabilitas sistem tenaga tetapi juga kehidupan orang dan operasi dalam muatan pesawat (Verma et al., 2018). Untuk menanggulangi masalah ini digunakan De-Icing Boot yang terdiri dari lapisan karet tebal yang terpasang di leading edge wing. Saat terjadi penumpukan es, system pneumatic mengembangkan boot dengan udara terkompresi. Perubahan ukuran boot dapat memecahkan es apapun yang menumpuk dan kemudian es tertiup angin. Setelah itu, boot dikempiskan untuk mengembalikan permukaan wing kebentutuk optimalnya. De-Icing Boot ini memiliki beberapa kelemahan, diantaranya boot perlu secara berkala diganti dua sampai tiga tahun, membutuhkan perawatan yang intensif, dan lubang pada boot dapat membuat kebocoran udara yang menurunkan efektivitas boot de-icing ini sehingga diperlukan kehatihatian dalam pemeriksaan sebelum penerbangan. Pada tingkatan yang sangat parah penggunaan boot saja tidak cukup karena es dapat menumpuk lebih cepat atau bahkan menumpuk pada permukaan non-boot sehingga mengganggu aliran udara yang berakhir pada gaya angkat (Francis, \& Eranga, 2014).

Laboratorium Internasional Bahan Antiicing (AMIL) telah menguji anti-icing/ de-icing SAE AMS1424 dan AMS1428 selama lebih dari 30 tahun. Dengan diperkenalkannya lapisan permukaan baru dan penyelidikannya sebagai sistem perlindungan es pasif yang potensial, atau untuk penggunaan hibrida dengan metode lain, hal yang sangat penting adalah memahami interaksinya dengan anti- icing/ de-icing di permukaan tanah sebelum aplikasi di pesawat (Villeneuve et al., 2019). Sistem termal pneumatic juga digunakan untuk mencegah pembentukna es atau untuk de-icing leading edge airfoil. system ini digunakan pada wing, leading edge slot, stabilisator horizontal and vertical, inlet pada mesin, dan lain-lain. Sistem ini memanfaatkan udara panas yang disalurkan pada sepanjang bagian dalam leading edge airfoid dan didistribusikan disekitar permukaan dalamnya. Ada beebrapa sumber udara panas, yaitu udara panas yang diambil dari kompresor turbin, penukar panas mesin (engine exhaust heat exchangers), dan udara luar yang diambil dan dipanaskan oleh pemanas pembakaran (Ramdhani, 2012).

Penanganan Icing pada pesawat semakin berkembang. Salah satu sistem terbaru yang dikembangkkan adalah electrical anti-icing. Sistem ini menggunakan pemanas yang besumber dari arus listrik sehingga dapat melelhkan es untuk kemudian dibuang oleh aliran pesawat terbang. Perkembangan sistem ini sangat bermanfaat dalam dunia penerbangan, oleh karena itu peneliti merancang suatu prototype dari alat electrical wing anti icing pada pesawat komersil dengan kelebihan dalam segi maintenance dan koponen yang lebih ringan.

Berdasarkan permasalahan yang telah dipaparkan, maka penelitian ini bertujuan untuk merancang suatu alat electrical wing anti icing berupa prototype dan dapat digunakan sebagai anti icing maupun de-icing.

\section{METODE PENELITIAN \\ Prinsip Kerja}

Perakitan prototype electrical wing anti-icing terdiri dari tiga bagian yang digambarkan melalui diagram yang dapat di lihat pada Gambar 1.

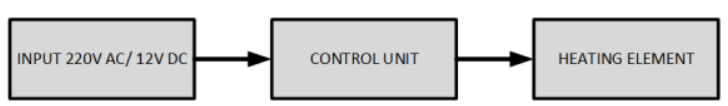

Gambar 1 Diagram prototype electrical wing anti icing pada Pesawat Komersil

Berdasarkan bagan pada Gambar 1. dapat diketahui bahwa pembuatan prototype electrical wing anti-icing ini terdiri dari input, control unit, dan heating element. Prototype menggunakan input tegangan $220 \mathrm{~V}$ AC dan $12 \mathrm{~V}$ DC yang merupakan tegangan rumah yang bertujuan untuk memudahkan pengoperasian. 
Bagian kedua dari prototype berupa control unit sebagai pusat pengendalian sistem pada prototype electrical wing anti icing pesawat. Bagian terakhir adalah heating element yang berperan sebagai komponen utama yang berfungsi untuk memanaskan permukaan wing. Sistem kerja heating element ini adalah dengan cara menempelkan heating element pada permukaan wing, maka ketika alat aktif melalui kontrol, heating element akan bekerja dengan indikasi LED yang menyala.

Control unit dapat bekerja jika tegangan yang dibutuhkan sudah terhubung (220V AC). Pada bagian control unit ini terdapat kontrol yang mengatur pengaktifan dan sistem automatic wing anti icing. Indikator aktif dan tidak aktifnya terdapat pada lampu LED. Terdapat tombol switch dimana jika ditekan tombol ON maka LED akan menyala yang mengindikasikan tegangan mengalir dan heater aktif memanaskan wing. Jika switch mengarah ke mode AUTO maka tegangan masuk pada IC LM 339 dan ULN2003 akan keluar melalui pin 3 yang kemudian menggerakkan relay dan menarik kontraktor sehingga alat ini langsung bekerja. Prinsip kerja dari IC ULN2003 ini yaitu bila diberi tegangan inputan pada IC ULN2003 sebesar 3,3 Volt maka pada bagian output IC ULN2003 akan terhubung ke tegangan (Ramdhani, 2012). Saat alat bekerja maka heater element yang ditempelkan pada media konduktor mulai bekerja memanaskan wing. Prototype ini juga menggunakan IC LM339 sebagai IC komperator (pembanding) untuk mengatur simulasi perubahan suhu. Perubahan suhu di ground tidak terlalu signifikan sehingga peneliti menggunakan simulasi perubahan suhu dengan menggunakan tegangan yang diatur menggunakan variabel resistor. Ada beberapa jenis variabel resistor seperti trimmer potensiometer (trimpot), slide potensiometer (slidepot) dan rotary potensiometer (potensio) (Daryanto, 2010).

\section{Alat dan Bahan}

Komponen yang diguankan pada pembuatan prototipe electrical wing anti-acing pada pesawat komersil dapat dilihat pada Tabel 1.

Tabel 1 Daftar Komponen yang Di Gunakan

\begin{tabular}{|l|l|l|l|}
\hline No. & $\begin{array}{l}\text { Nama } \\
\text { Komponen }\end{array}$ & Jenis & $\begin{array}{l}\text { Jum } \\
\text {-lah }\end{array}$ \\
\hline 1 & Resistor & $10 \mathrm{~K} \Omega \pm 5 \% \frac{1}{2} \mathrm{~W}$ & 1 \\
\cline { 3 - 4 } & & $5 \mathrm{~K} \Omega \pm 5 \% \frac{1}{2} \mathrm{~W}$ & 1 \\
\hline 2 & $\begin{array}{l}\text { Resistor } \\
\text { Variabel }\end{array}$ & $50 \mathrm{~K} \Omega$ & 1 \\
\hline 3 & LED & Kuning & 1 \\
\hline 4 & Relay & $12 \mathrm{~V}$ DC $10 \mathrm{~A}$ & 2 \\
\hline 5 & Switch & Rotary SW & 1 \\
\hline 6 & IC & Lm 339 & 1 \\
\cline { 3 - 4 } & UN 2003 & 1 \\
\hline 7 & $\begin{array}{l}\text { Heating } \\
\text { Element }\end{array}$ & 10 watt & 1 \\
\hline
\end{tabular}

\section{Langkah Kerja}

1. Pembuatan Rangkaian Menggunakan PCB Dot Matrix

Printed Circuit Board (PCB) merupakan papan yang digunakan untuk mendukung semua komponen-komponen elektronika yang berada diatasnya. PCB dapat dilihat pada Gambar 2.

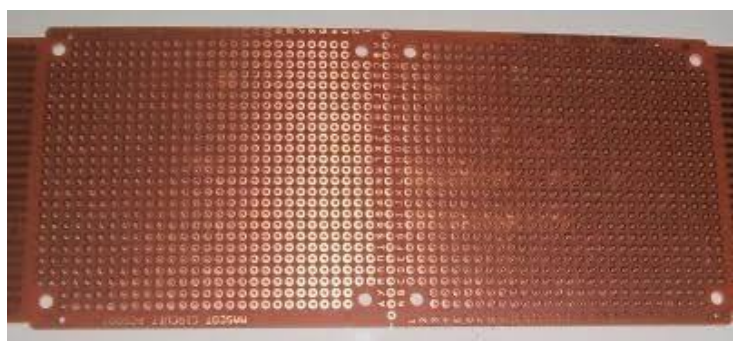

Gambar 2 PCB Dot Matrix

PCB Dot Matrix memiliki lapisan konduktor yang terbuat dari tembaga dan berfungsi untuk menghubungkan antara satu komponen dengan komponen lainnya dengan cara disolder. 
2. Layout Rangkaian Tampak Atas dan Bawah Layout Rangkaian Tampak Atas dan Bawah dapat dilihat pada Gambar 3 dan Gambar 4.

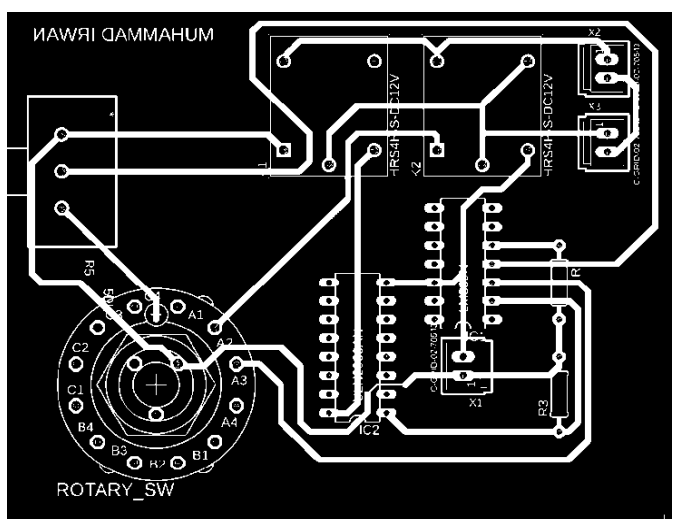

Gambar 3 Tampak Atas Layout Rangkaian

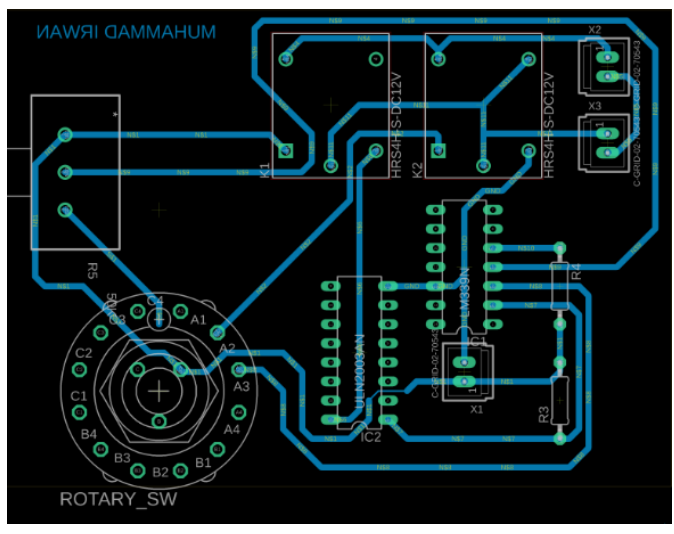

Gambar 4 Tampak Atas Layout Rangkaian

Layout tampak atas dan bawah rangkaian prototype electrical wing anti icing pada pesawat komersil menggunakan aplikasi Eagle 9.5.1.

3. Pemasangan Komponen

Pemasangan komponen pada PCB dapat dilihat pada Gambar 5 dan Gambar 6.

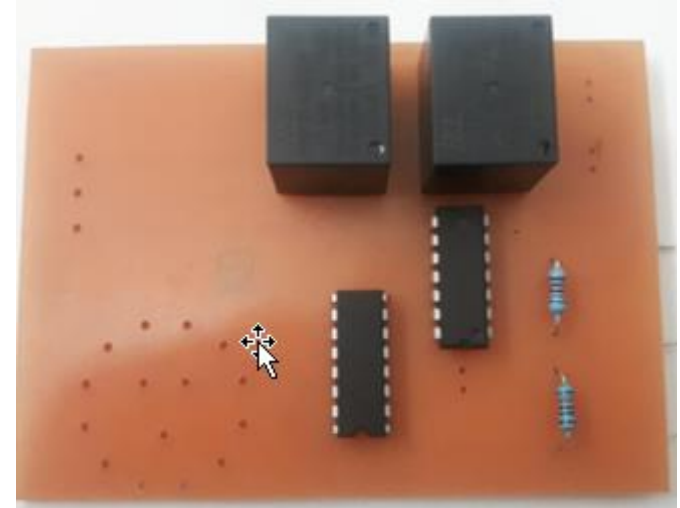

Gambar 5 Pemasangan Komponen pada PCB

Copyright $\odot 2020$ Jurnal Jaring SainTek Oktober 2020

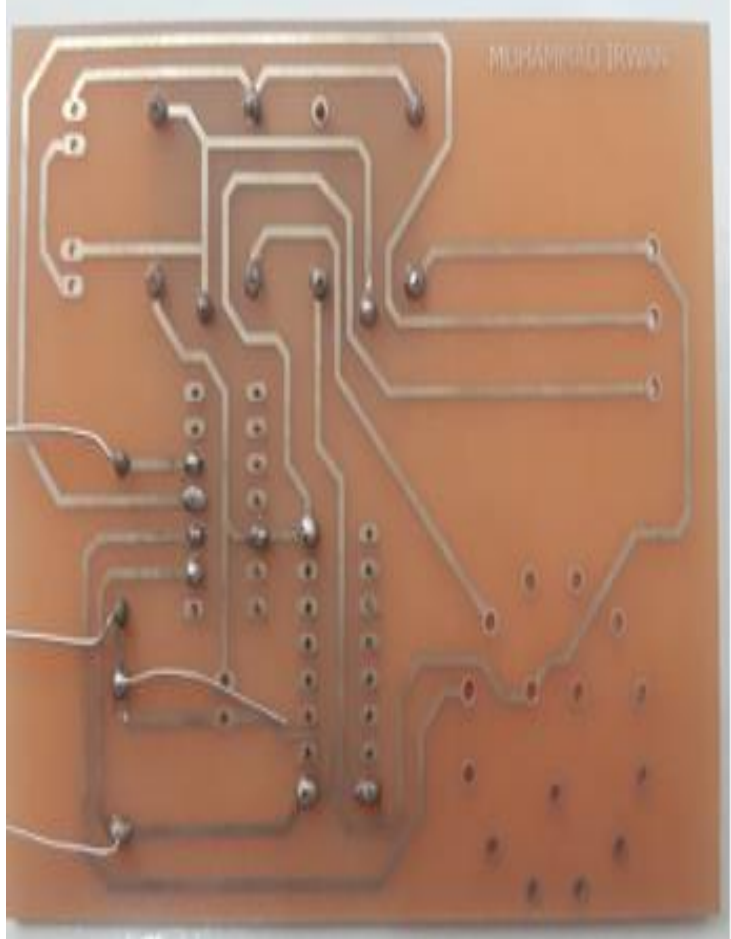

Gambar 6 Penyolderan Komponen pada PCB

Setelah pemasangan komponen, selanjutnya dilakukan tahap penyolderan komponen pada papan PCB.

4. Pengemasan dan Peletakan Masing-Masing Bagian

a. Kotak Indikator dan Kontrol

Rangkaian komponen dilengkapi dengan kotak indikator dan kontrol yang dapat dilihat pada Gambar 7.

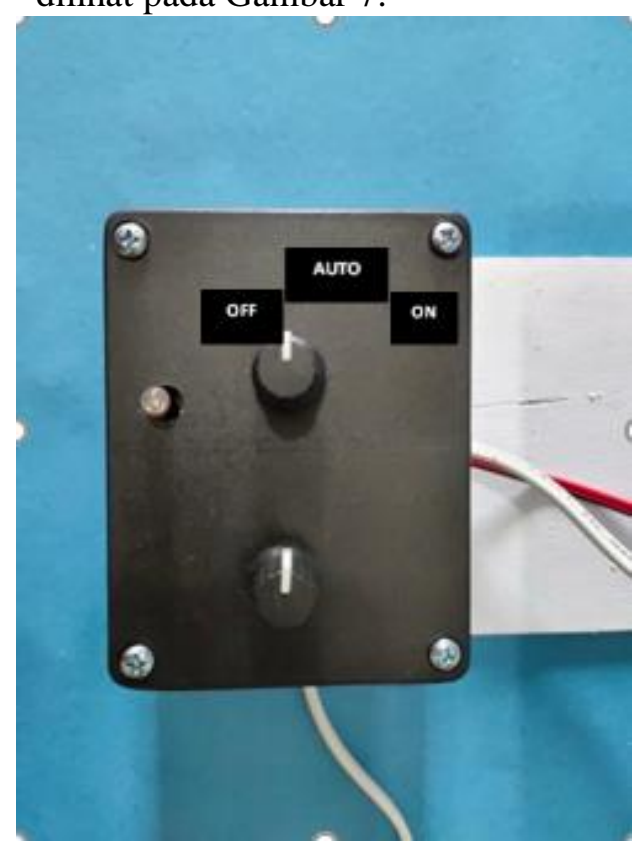

Gambar 7 Kotak Pengemasan

Peneliti menggunakan kotak sebagai 
penempatan komponen seperti Gambar 7 .

Kotak tersebut memiliki ukuran panjang, lebar, dan tinggi masing-masing $10 \mathrm{~cm}, 10$ $\mathrm{cm}$, dan $5 \mathrm{~cm}$.

b. Media Kontrol Wing

Pada prototype digunakan suatu media kontrol wing seperti pada Gambar 8.

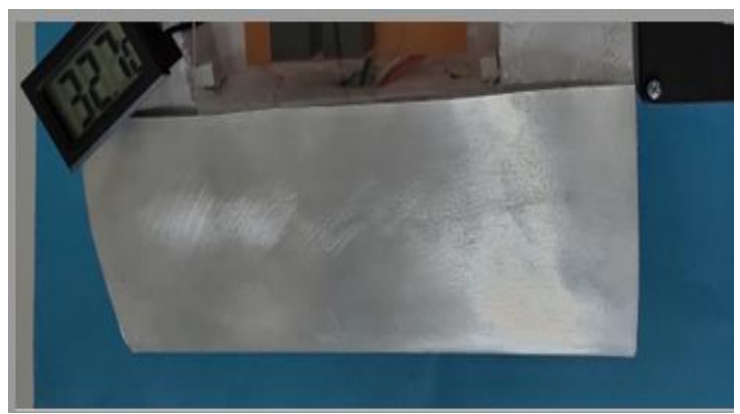

Gambar 8 Media Kontrol

Media konduktor yang digunakan pada penelitian ini terbuat dari aluminium untuk meletakkan elemen pemanas dengan ukuran panjang, lebar, dan tebal masingmasing $22 \mathrm{~cm}, 4 \mathrm{~cm}$, dan $5 \mathrm{~mm}$.

c. Hasil Pengemasan

Hasil pengemasan prototipe electrical wing anti icing pada pesawat komersil dan komponen penunjangnya semua komponen dapat dilihat pada Gambar 9 dan Gambar 10.

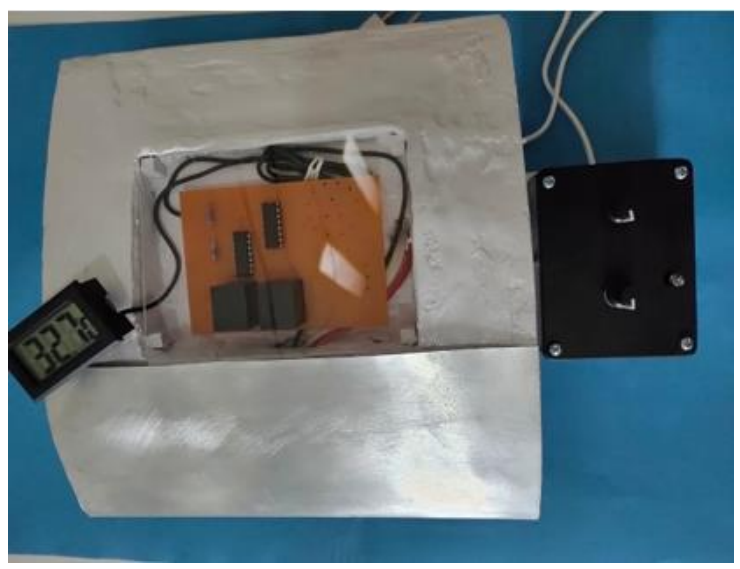

Gambar 9 Simulasi Prototype Electrical Wing Anti Icing

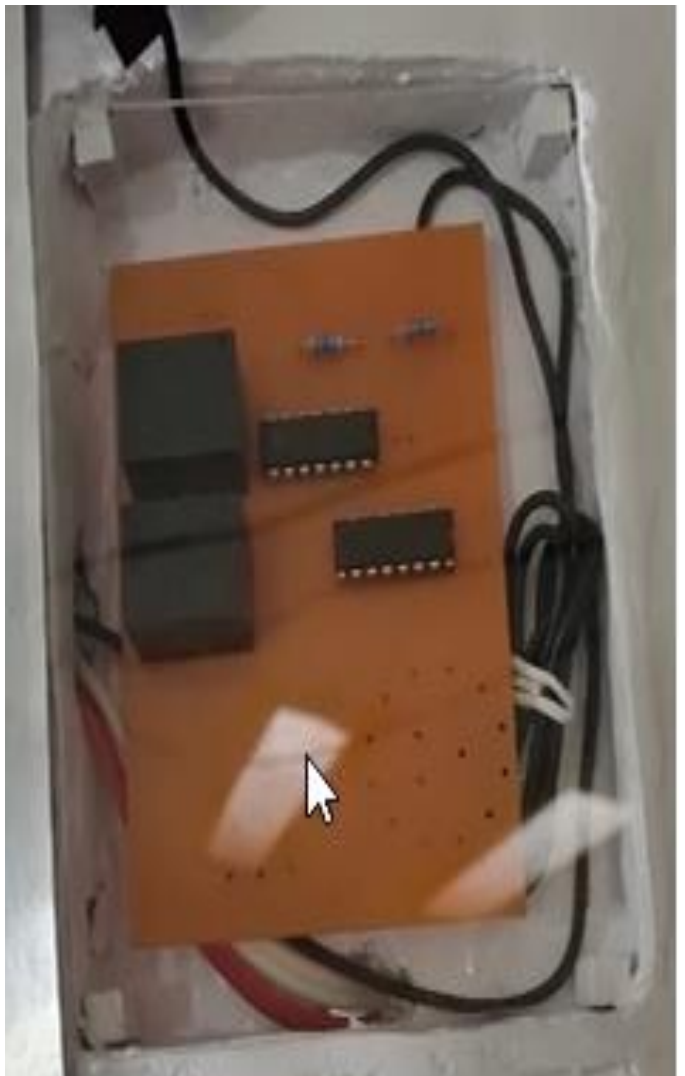

Gambar 10 Rangkaian Prototype Electrical Wing Anti Icing dan Komponen Penunjangnya Pengemasan dibuat agar alat terlihat rapi dan leih gampang dalam pengoperasiannya.

\section{HASIL DAN PEMBAHASAN}

Uji Fungsi Prototype Electrical Wing AntiIcing pada Pesawat Komersil

Pengetesan alat sangat penting untuk dilakukan untuk melihat apakah komponenkomponen dan peralatan yang dirakit sudah sesuai dengan yang diharapkan atau masih perlu perbaikan. Pengetesan alat dilakukan pada suhu luar ruangan, yaitu sekitar $31,3{ }^{\circ} \mathrm{C}$ (Gambar 11).

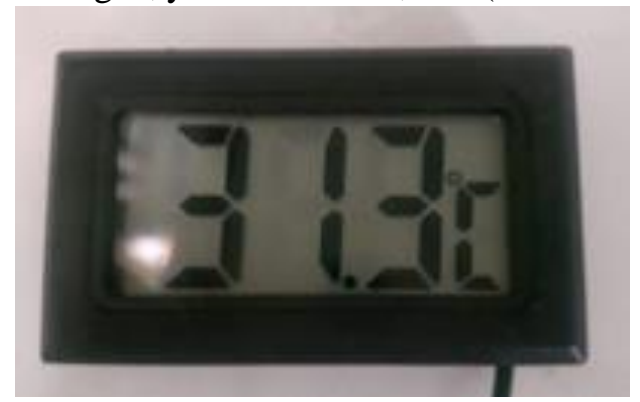

Gambar 11 Suhu Luar Ruangan

Setelah menetapkan suhu luar ruangan, alat dihubungkan pada sumber listrik rumah tangga dengan tegangan $220 \mathrm{~V}$ AC seperti yang dapat dilihat pada Gambar 12. 


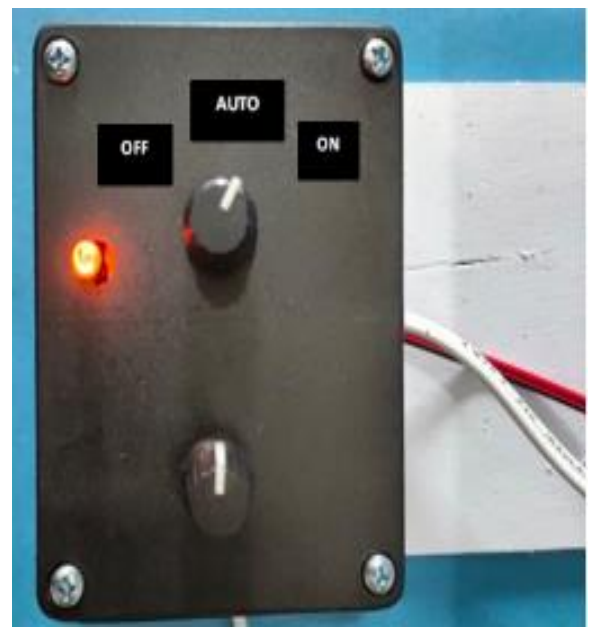

Gambar 12 Sistem dalam Posisi ON (Indikator LED Menyala)

Setelah alat dihubungkan dengan sumber tegangan, kemudian posisikan switch pada posisi ON. Jika alat bekerja dengan baik maka saat ON lampu indikator LED akan menyala yang mengindikasikan alat dalam posisi heater sedang bekerja dan thermometer menunjukkan kenaiakn suhu pada heater seperti yang dapat dilihat pada Gambar 12. Switch juga dapat diarahkan pada posisi AUTO seperti yang terlihat pada Gambar 13.

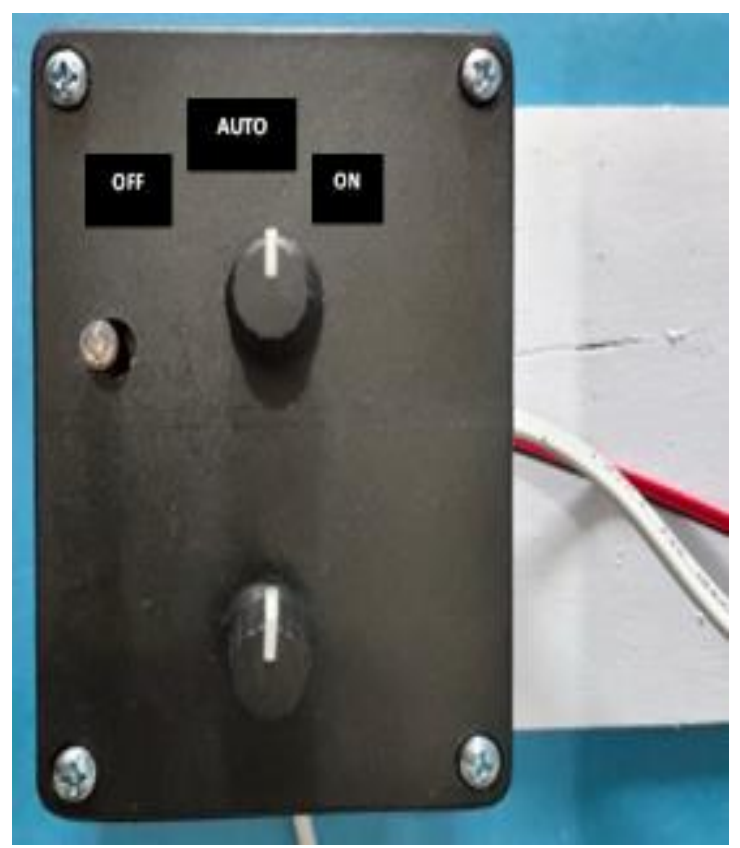

Gambar 13 Sistem dalam Posisi ON (Indikator LED Menyala)

Pada posisi AUTO maka LED akan mati secara otomatis yang mengindikasikan bahwa alat ini tidak sedang bekerja karena suhu perlahan turun. Setelah switch simulasi perubahan suhu
Electrical Wing Prototype Anti Icing pada Pesawat Komersil dialihkan ke $12 \mathrm{~V}$ DC, maka secara otomatis elemen pemanas bekerja memanaskan permukaan wing dan secara bersamaan LED menyala. Jika switch simulasi perubahan suhu beralih ke tegangan 6V DC, maka secara otomatis alat tidak bekerja memanaskan permukaan wing dan secara bersamaan LED akan mati. Jika arus listrik terputus, maka LED juga akan mati.

\section{Hasil Uji Fungsi}

Setelah dilakukan Uji fungsi, didapatkan hasil uji fungsi yang dapat dilihat pada Tabel 2 .

Tabel 2 Peningkatan Suhu Terhadap Waktu

\begin{tabular}{|l|l|l|}
\hline Waktu (s) & Suhu $\left({ }^{0} \mathrm{C}\right)$ & Suhu $\left({ }^{0} \mathrm{~F}\right)$ \\
\hline 0 & 30 & 86 \\
\hline 20 & 42 & 107,6 \\
\hline 40 & 59 & 138,2 \\
\hline 60 & 74 & 165,2 \\
\hline 80 & 90 & 194 \\
\hline 100 & 95 & 203 \\
\hline 120 & 97 & 206,6 \\
\hline 140 & 102 & 215,6 \\
\hline
\end{tabular}

Jika dibuat dalam bentuk grafik, maka didapatkan bentuk grafik pada Gambar 14 .

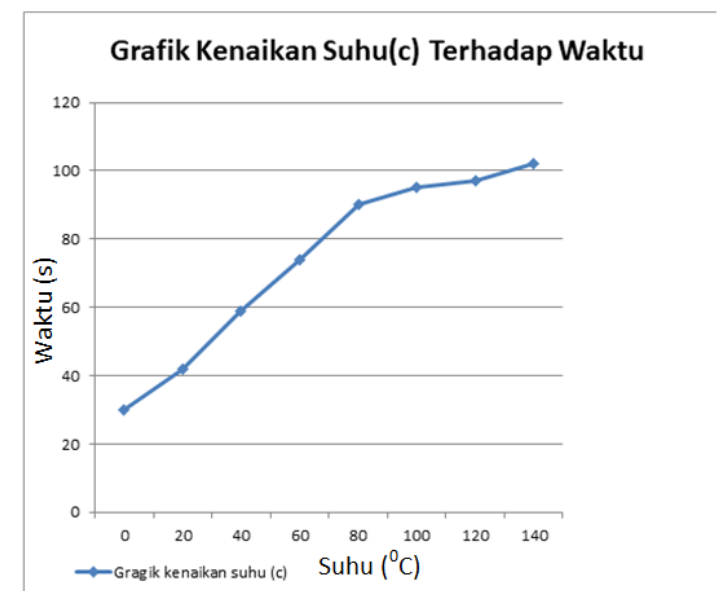

Gambar 15 Grafik Kenaikan Suhu Terhadap Waktu

\section{Pembahasan}

Prinsip kerja pada alat prototype electrical wing anti icing ini adalah dengan memanaskan sebuah elemen pemanas yang ditempelkan langsung pada permukaan konduktor leading edge pada wing pesawat, sistem ini dikontrol secara manual dan otomatis oleh sebuah IC LM339 yang berfungsi membandingkan tegangan yang bekerja pada 
Submitted: 20/10/2020; Revised: 26/10/2020; Accepted: 28/10/2020; Published: 30/10/2020

alat ini. Alat ini akan menghubungkan atau memutus arus listrik ke elemen pemanas ketika dua tegangan yang memasuki LM339 terdapat perbedaan sebagai simulasi perubahan suhu, dengan nyala dan matinya LED sebagai indikator. Alat ini masih menggunakan rangkaian analog.

Pada uji fungsi yang menggunakan beberapa tegangan untuk meningkatkan suhu pada heater element, dapat dilihat dari Tabel 2 dan Grafik 1 bahwa suhu terus naik seiring dengan waktu. Hal ini membuktikan bahwa prototype ini dapat berfungsi dengan baik sebagai alat anti-icing pada wing pesawat komersil. Heater element dapat memecah es yang menumpuk pada wing pesawat komersil.

Pada saat dilakukan pengetesan dengan keadaan suhu ruangan $31,3^{\circ} \mathrm{C}$, peneliti mengamati kenaikan suhu pada saat alat ini baru bekerja dengan menggunakan termometer yang ditempel di elemen pemanas sehingga dapat mengetahui jumlah kenaikan suhu yang terjadi pada saat alat bekerja dari awal dinyalakan sampai alat mati secara otomatis. Hasil kenaikan suhu dari sistem ON atau normal sampai dengan batas waktu yang telah diatur adalah $30^{\circ} \mathrm{C}-100^{\circ} \mathrm{C}$ dan rata-rata kenaikan suhu per 20 seconds adalah $10^{\circ} \mathrm{C}$. Suhu ruangan berpengaruh dalam proses pemanasan dari heater element tersebut.

Electrical wing anti icing pada pesawat komersil memiliki input power, wing ice protection controller, heating element, dan data networ menggunakan tegangan $235 \mathrm{~V}$ AC untuk heater power, dan 28V DC control power supply. Perbandingan dengan prototype electrical wing anti icing pada pesawat komersil dibuat dengan bagian-bagian yang terdiri dari Input, Control unit, dan Heating Element menggunakan tegangan $220 \mathrm{~V}$ AC untuk heater, dan tegangan $12 \mathrm{~V}$ DC control unit.

\section{KESIMPULAN DAN SARAN}

Setelah dilakukan uji fungsi prototype electrical anti-icing dapat dimanfaatkan sebagai de-icing yang menghilangkan icing yang sudah terlanjur membeku pada leading edge. Pada prototype ini digunakan switch yang dapat mengatur mode MANUAL dan AUTO dengan menggunakan energi listrik yang dihubungkan ke heater element sebagai sumber panas. Mode AUTO digunakan untuk meningkatkan efektivitas kerja heater karena hanya aktif saat diperlukan saja. Tegangan input yang digunakan pada prototype ini $220 \mathrm{~V}$ AC yang bertujuan mempermudah simulasi karena sama dengan tegangan rumah tangga.

Pada prototype ini masih banyak terdapat kekurangan. Untuk pengembangan selanjutnya disarankan untuk membuat alat dengan menggunakan perubahan suhu yang real dan menggunakan thermostat sebagai sensor suhu.

\section{DAFTAR PUSTAKA}

Battisti, L., Baggio, P., \& Fedrizzi, R., (2006). Warm-Air Intermitternt De-Icing System for Wind Turbines. SAGE Journals, doi.org/10.1260/030952406779502713.

Daryanto. (2010). Keterampilan Kejuruan Teknik Elektronika. Satu Nusa: Bandung. Journal of Software, 6(11 SPEC. ISSUE), 2114-2120. doi:10.4304/jsw.6.11.2114-2120

Francis, K., \& Eranga. (2014). Anti-Icing \& DeIcing System. Emirates Aviation University

Landau, K., Nadeau, S., Floch, T. L., \& Morency, F. (2017). Ergonomic Time anda Motion of Aircraft De-icing Work. Journal of Ergonomics, 7(04), doi: 10.4172/2165-7556.1000204

Morita, K., Kimura, S., \& Sakaue, H. (2020). Hybrid System Combining Ice-Phobic Coating and Electrothermal Heating for Wing Ice Protection. Aerospace, 7(8), 102, doi.org/10.3390/aerospace7080102

Ramdhani, I. (2012). Aplikasi Driver Relay ULN2003 Sebagai Penggerak Konveyor pada Otomatis Pengelompokkan Buku Menggunakan Inisialisasi Barcode. Polsri.

Sarshar, M. A., Song, D., Swarctz, C., Lee, J., \& Choi, C. H. (2018). Anti-Icing or DeIcing: Icephobicies of Superhydrophobic Surface with Hierarchical Structures. ACS Publications, 2018, 34, 46, 1382113827 , doi.org/10.1021/acs.langmuir.8b02231.

Uranai, S., Fukudome, K., Mamori, H., Fukushima,N \& Yamamoto, M. (2020). Numerical Simulation of the Anti-Icing Performance of Electric Heaters for Icing on the NACA 0012 Airfoil. Aerospace, 
7(9), 123, doi.org/10.3390/aerospace7090123.

Villeneuve, E., Brassard, J. D., \& Volat, C. (2019). Effect of Various Surface Coatings on De-Icing/Anti-Icing Fluids Aerodynamic and Endurance Time Perfomances. Aerospace, 6(10), 114; doi.org/10.3390/aerospace6100114, $\quad(9$ October 2019)
Electrical Wing Prototype Anti Icing pada Pesawat Komersil Verma, P. S., Raj, B. S. S., Sainath, S., \& Rao, F. (2018). A Review on Current Methods of De-Icing and an Idea for Designing an Autonomous Robot for De-Icing. International Journal of Engineering \&Technology, 7(1.8) page 182-187. 